\title{
Effective use of scientific cum technologically achievements and financing innovative projects in the agricultural sphere
}

\author{
Babadjanov Abdirashid Musayevich \\ Uzbek Research Institute of Market Reforms, Tashkent, Uzbekistan; pirbobo@mail.ru
}

Received 28 December 2010; revised 5 January 2011; accepted 19 January 2011

\begin{abstract}
Justified the urgency of modernization and retooling of production in agriculture, which is an important sector in the economy of the Republic of Uzbekistan. The author describes the problems of extending the research in agriculture, the implementation of its results into production and increasing innovation activity. Also has considered the possibility of extra-budgetary funding of research in agrarian sector, and given a recommendation on the use of bank loans by (dehkan) private households, farmers and other stakeholders in the financing of scientific research. The findings based on sociological survey, among the different farms on the use of innovative ideas for development of production. Offered mechanism of funding, the implementation of scientific production, as well as providing market participants of the scientific and technical products allows removing the shortage of financial resources. The main directions of investment mobilization has been identified in the research process from extrabudgetary funds. Statistical data reflecting the amount of agricultural land use in Uzbekistan has adduced and its structure in key areas. Here is given the number of farms operating as a major agricultural producer of the leased land area and the state long-term basis. Also, describes the main problems of agricultural producers, hindering the development of production of marketable products. In this paper, the main attention is shown the importance of innovative ideas for further development of the agricultural sector as a basis for providing people with food today and in the future.
\end{abstract}

Keywords: Research and Technological

Achievements of the Agrarian Sector; Innovation;

Research; Financing and Bank Loans

\section{INTRODUCTION}

Uzbekistan is the largest agricultural producer in Central Asia (See Annex 1 and 2). The total land area of the Republic is 44.410 .3 hectares. Out of it, more than 25.645 hectares is used for agricultural purposes (including irrigated land 4278 million hectares), pastures $21.367,000$ hectares, forests 3221.8 thousand hectares and 15543.5 thousand hectares of others. Majority of agricultural products produced on irrigated lands, pastures, in turn, are a source of feed for livestock. At present, the agricultural production is predominant in the two forms of management: farmers and dehkan farms (Dekhkan - In Uzbekistan an owner of a household croft). Farmers are the major producers and have a large area of land. Dekhkan farms are small farms producing agricultural products. The average area of land of farmer households, on average from 0.15 hectare to 1.0 hectare, while the average acreage of farms formed the basis of their specialization and direction of production.

In condition of 2010 in the Republic were about 81 thousand farms, which were active on land leased from the state on a long term basis. The term of the lease is 49 years with possibility of extension. Peasantries land is given to peasants for a lifetime lease with the right to transfer by inheritance (Figure 1) [1].

Currently, the main problems of agricultural production are:

- Lack of necessary equipment, and physical obsolescence of existing technology;

- High growth rates of price makes difficult to purchase material and technical resources necessary for production;

- The establishment and development of infrastructure serving the agricultural production is slow;

- Development of storage, processing and delivery to consumers of agricultural products have not yet met the high requirements of the market;

- Long period of application period for achievement of science and technology, a bad relationship of science and 


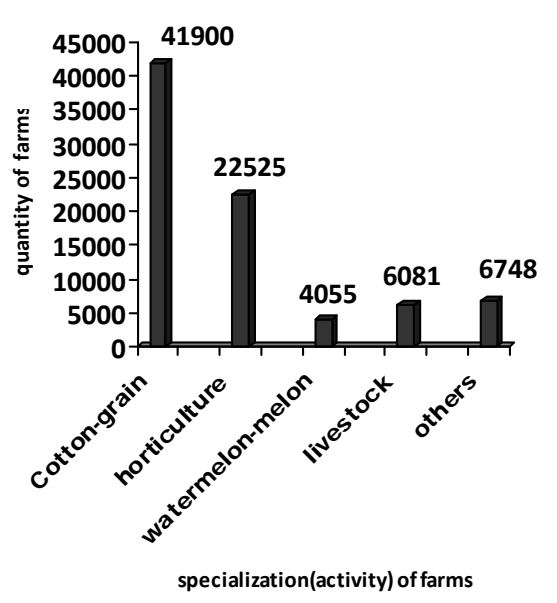

Figure 1. Number of farms and their activities in Republic of Uzbekistan on 01.01.2010.

production etc.

Due to the above mentioned problems profitability of agricultural production is rising slowly. In our opinion, paramount solution of these problems is the modernization, technical and technological renewal of production. One of the main directions of achievement of this goal is the widespread use of science and technology in the agricultural sphere and radical improvement of the mechanism of financing of innovative projects. It is known that the economic prosperity of any country is directly linked and determined by the level of the existing scientific potential, the effective use of the results of its activities in the production. Employees of the scientific sphere with his new ideas, practical developments directly and indirectly contributing to the economic development of society.

Increased demand in society for the science to the development of production contributes to a more active implementation of scientific and technological products in the manufacturing process, which ultimately improves the volume and profitability of agricultural production.

Therefore, it is most urgent and priority to select the areas of research related to the development of the agrarian sector, as well as to improve its financial mechanism [2].

Each stage of the agrarian reforms in Uzbekistan is characterized peculiar problems of this phase. With the deepening of economic reforms, together with increased production in the agricultural sector become important task of raising the competitiveness of agricultural products. In order to improve the competitiveness of products, along with the introduction of modern techniques and technologies, best practices in agriculture, advances in science it is important to pay great attention to the ecological balance.

Science, research organizations, scientists directly contributed to the ideas of socio-economic development of society. By definition of the Russian scientist I.S. Sandu innovative processes in the agricultural sector is a constant and continuous transformation of scientific research, organizational, technological and technical ideas in the technology of production of quality products, reduce squandering and increase production efficiency. According to I. S.Sandu, main actors in this process are scientific and educational institutions related to agriculture, agricultural authorities, organizations and farmers [3].

According to another outstanding Russian scientist I. Ushacheva economic research conducted to the agricultural sector is a source of innovation of the industry. Industry has to be developed through the introduction of scientific developments, which should be financed by the state. However, this needs to take into account the increase of the financial interest of researchers. First, need to introduce the achievements of science in industry, taking into account region-specific (soil, climate, etc.). That is important to develop the concept of development of the agrarian sector and its financing at the country level [4].

E. Ogloblin in their scientific research states the following: research funding, primarily, should be on a competitive basis based on the results, to be scientifically valid, of budgetary and extra budgetary funds.

With funding of agricultural science also needs attention to the following aspects:

- Modernization of the administrative staff of Agricultural Academy and its constituent research institutions;

- Organization of integration of research centers of various directions;

- Promotion of cooperation ties between research institutes, etc [5].

In our opinion, for the efficient organization of scientific supplies agriculture appropriate to consider the following important factors:

- Identify topics of practical and innovative research based on the existing problems of the agricultural sector;

- Mutual conducting of scientific research in fundamental and practical areas;

- Implementation of applied research in the form of innovative projects [6].

Joint implementation of these directions will enable a stable system of scientific provision of agriculture sector and render a positive impact on the results of its operations. The accelerated introduction of innovative advances in the production process is raising incomes of commodity producers, especially large farmers. In order to determine the role of innovative products in the activities of farms and estimate the demand for these 
products in the two regions of the country among the farms of the different districts, a sociological survey was conducted.

During the survey 78 farms in the Samarkand region and 56 farms in the SyrDarya region were selected, along with, evaluating the effectiveness of the farm activities and relation of innovation and innovative products has been studied. Based on the analysis of the results of the survey were rated how innovative products affect the efficiency of farms in the present (Table 1).

The essence of the first question was as follows:

- How did you get information about outstanding innovation and innovative products?

Response options were as follows:

1) From the news media;

2) By contacting the information and consulting firm;

3) At meetings, congresses and meetings organized by local governments;

4) During treatment with the suggestion of scientific institutions engaged in the creation of innovative products;

5) During treatment with the proposal of sale dealer firms newly established products (seeds, varieties, tech- nology, equipment, drugs, etc.);

6) To local and international exhibitions and fairs;

7) Itself directly involved in cooperation with scientific institutions in the creation of innovative products and innovations.

The results of our studies showed that for most farms (26\%) the main source of information on innovative products are dealer firms, which sell this product.

The second most important source of information for most farms (24\%) is congresses and meetings organized by local authorities. In addition, significant proportion of these sources is the media (18\%) on local and international exhibitions $(15 \%)$ in obtaining information about innovative products (Figure 2).

However, only $6 \%$ of farmers indicated that information about innovations are in the institutions involved in the creation of innovative products.

Farmers who are directly involved in collaboration with academic institutions in the creation of innovative innovations and products, amounted to only 3 percent among those surveyed.

These figures show that the academic institutions, which directly create innovative products, have a very

Table 1. Information on surveyed farms.

\begin{tabular}{|c|c|c|c|c|c|}
\hline \multirow{2}{*}{ № } & \multirow{2}{*}{ Regions } & \multicolumn{4}{|c|}{ Farms } \\
\hline & & Directions of activity & Average area of land & Number of surveyed & Relatively to total \% \\
\hline \multirow{5}{*}{1} & \multirow{5}{*}{ Samarkand region } & $\begin{array}{l}\text { Cotton-growing-leguminou } \\
\text { s plants }\end{array}$ & 90,5 & 36 & 46 \\
\hline & & $\begin{array}{l}\text { Vegetable and -gourd } \\
\text { growing }\end{array}$ & 26,4 & 14 & 18 \\
\hline & & livestock & 48,6 & 5 & 6 \\
\hline & & horticulture & 12,4 & 20 & 26 \\
\hline & & others & 4,5 & 3 & 4 \\
\hline \multirow{4}{*}{2} & \multirow{2}{*}{\multicolumn{2}{|c|}{$\begin{array}{l}\text { All per region } \\
\text { Cotton-growing-leguminou } \\
\text { s plants }\end{array}$}} & 36,5 & 78 & 100 \\
\hline & & & 58,7 & 24 & 43 \\
\hline & \multirow[t]{2}{*}{ Sirdary region } & $\begin{array}{l}\text { Vegetable and -gourd } \\
\text { growing }\end{array}$ & 7,2 & 12 & 21 \\
\hline & & Livestock & 34,6 & 6 & 11 \\
\hline
\end{tabular}

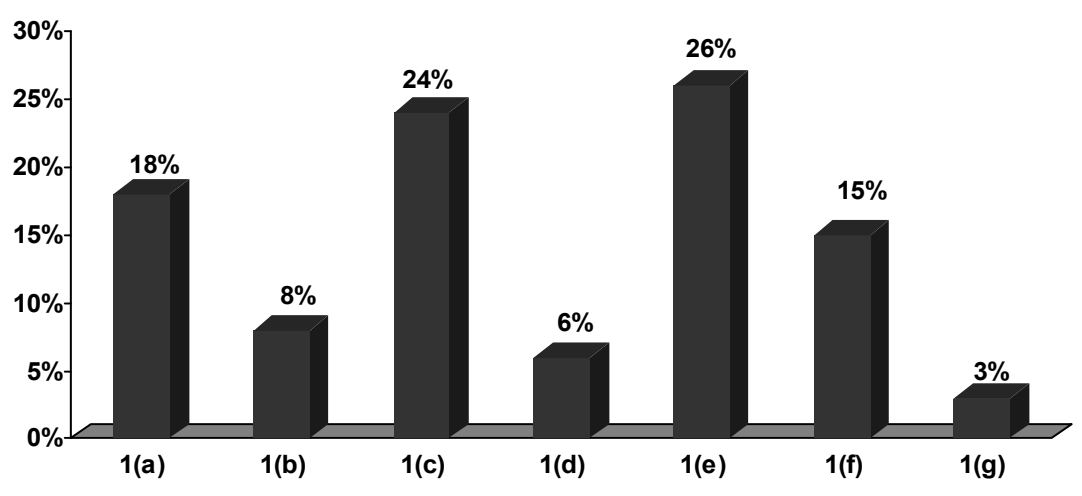

Figure 2. Sources of information of farms about the innovative products. 
low share in the dissemination information on the results of its activities.

The next question that we asked the farmers was aimed at determining their readiness to cooperate with academic institutions to create innovative products.

To the question: "Would you like to collaborate with academic institutions in the creation of innovative products and finance the process?" the following answers were received:

1) My farm, and so well developed;

2) I do not believe that innovative products, they have created positive impact on the development of my farming;

3) I am ready to experience the products they create and allocate the land to carry out various experiments;

4) It is better to get ready innovative products created by research institutions;

5) I am ready to cooperate with research institutions to create innovative products and finance this process;

6) Only in case if an innovative product will be the property of my farm with the right of resale.

Our research has shown that farmers have a positive attitude to cooperation with scientific institutions in the creation of innovative products and partial financing of this process. Thus, 67 farms (35\%) indicated their willingness to cooperate with academic institutions to create innovative products. $14 \%$ of respondents are willing to cooperate and finance, as if creating innovative products will become the property of the farm. The share of farms who prefer to buy ready-innovative product was $18 \%$. At the same time $5 \%$ of farms surveyed had a negative reaction to the idea of cooperation with research institutions (Figure 3).

In our research, we examined in the creation of any innovative products interested farmers. So the question:

"What innovative products you need to develop and improve the efficiency of your farm?" There were following answers:
1) Quality and competitive seeds, seedlings, pedigree cattle;

2) Agricultural equipment and machinery which providing high-quality farming practices;

3) New technologies for storing, processing and packaging of agricultural products;

4) Necessary to improve the supply of organic and mineral compounds and fertilizers, allowing for timely implementation of agricultural activities;

5) Establishment of modern biological control of pests and diseases of plants and animals;

6) Necessary to form information system that promotes the effective administration and management of farms.

Most farmers (28\%), its development is associated with such innovative products as high quality and competitive seeds, seedlings, pedigree cattle, etc. The share of other answers are more evenly distributed and ranged from 12 to $16 \%$ (Figure 4).

\section{CONCLUSIONS}

Based on the above studies it can be argued that the system of research support of the agrarian sector must be developed by increasing the supply of agricultural qualified personnel, the use of economic management, to achieve closer links between science and production. The effectiveness of scientific support of the agrarian sector is dependent on research funding. In recent years financial constraints have led to a decline in basic and applied research, which in turn reflected in the declining quality of research solutions. Therefore, in market conditions in order to improve research support for the agrarian sector it is important to create a theoretical basis for the mechanism of financing of research, which will use the financial resources to customers with innovative products.

Scientific support of the agrarian sector is the demand for agricultural science and technology for the development of agricultural production, improving agricultural

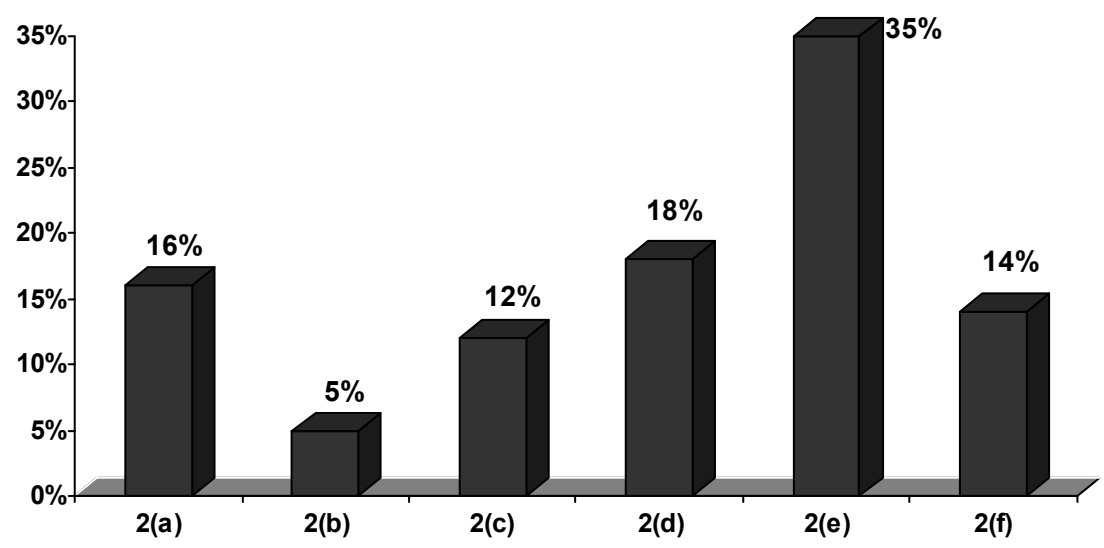

Figure 3. Readiness farms to cooperate with research institutions to create innovative products. 


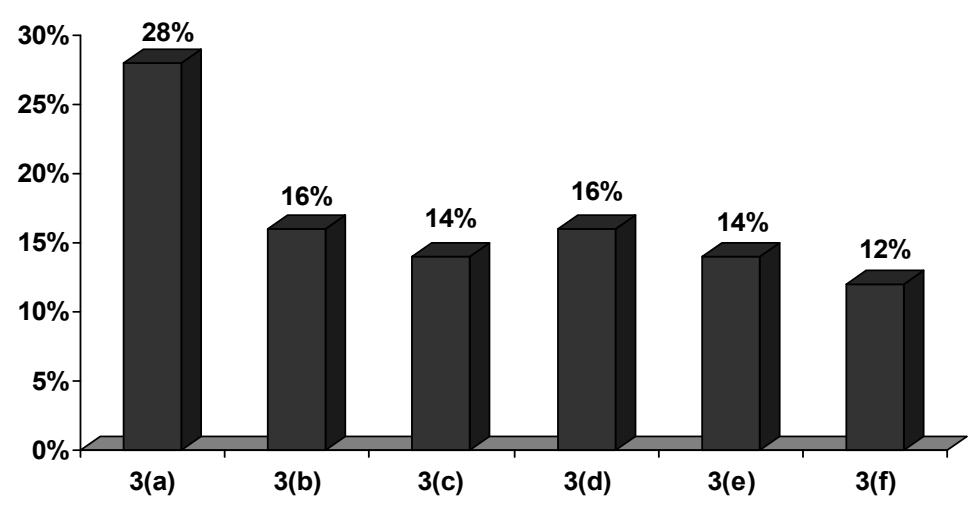

Figure 4. What are the innovative products you need to develop and improve performance of your farm?

production through the introduction of scientific solutions to production.

In agriculture must be ready to turn scientific-research solutions in commercial products. The ultimate scientific decisions can be: new varieties, sorted and prepared for sowing seeds, production technology, well, methods of planting, processing, pest and diseases, harvesting, management mechanisms, etc.

As shown by our investigations, at present, most farmers are not ready to buy scientific solutions in the form of goods. Therefore, it is necessary to improve system of implementation of the ultimate scientific solutions in production.

In our opinion, to solve this problem is first necessary to develop a mechanism for state support. State support should not be in the budget financing, as well as providing long-term soft loans, tax incentives, improving the mechanism of stimulation and etc.

In this case farmers and other agricultural producers, as well as organizations of infrastructure in this field engaged in the implementation of scientific and technical results will apply to commercial banks to receive credit for introducing innovative products into production. To promote the interest of commercial banks, research institutions, consumers of research products, in action of this mechanism, it is necessary to develop a system of tax privileges. The application of this funding mechanism, the introduction of research products, firstly, motivates academic institutions choose topics based on the analysis of demand, the market products.

Second, consumers of scientific production more seriously and reasonably would relate to decision-making about introduction of some innovative products in its production. In turn, giving loan to market participants to ensure scientific and technological products will remove the problem of lack of financial resources.

The recommended method of implementation the re- search output does not require the allocation of budgetary funds to the this process, however, increases the amount of the product and improves its quality, as well as reduce production costs and improve competitiveness.

In addition, the system of funding research projects of agriculture must be intensified to attract extra-budgetary funds. To do this:

- It is necessary to develop a system to utilize various sources of funding for research and implementation of its results into production;

- Use bank loans to finance the implementation of research results into production, as well as to develop economic and legal mechanisms for encouraging banks;

- To increase research to develop a legal framework for participation in this process, private sector, including private entities;

- It is necessary to develop scientific research institutions and their infrastructure, leading its work on the laws of the market and specializes in scientific production.

Thus, through the involvement of producers to participate in scientific research, its funding and implementation of the results can be achieved stable development of agriculture.

Financing in adequate level of agricultural science, the implementation of its achievements in production will increase opportunities for people of good quality and less expensive food, to solve the challenges of regular supply of raw materials, processing plants, which ultimately have an impact on raising the level and quality of life.

\section{REFERENCES}

[1] Uzbekistan in figures. Materials of State Statistics committee of Republic of Uzbekistan (2010) Tashkent, Uzbekistan.

[2] A. Babadjanov (2010) Main directions of scientific sup- 
port for agriculture in Uzbekistan in the development of farms. Economics and Finance, 36-38 Art.

[3] J. Sandu (1990) Production and scientific-production system-An effective form of integration of science and production. Nauka, 73 .

[4] I. Ushachev (2006) Scientific support of government programs for agriculture in Russia. Nauka, 9.

[5] E. Ogloblin. (2005) Development of research institutions and their activities in a condition of market economy. Nauka, 32.

[6] A. Babadjanov. (2007) Improve financing of agricultural science. AIC: Economics, Management, Moscow, 12.

Annex 1. Map Republic of Uzbekistan

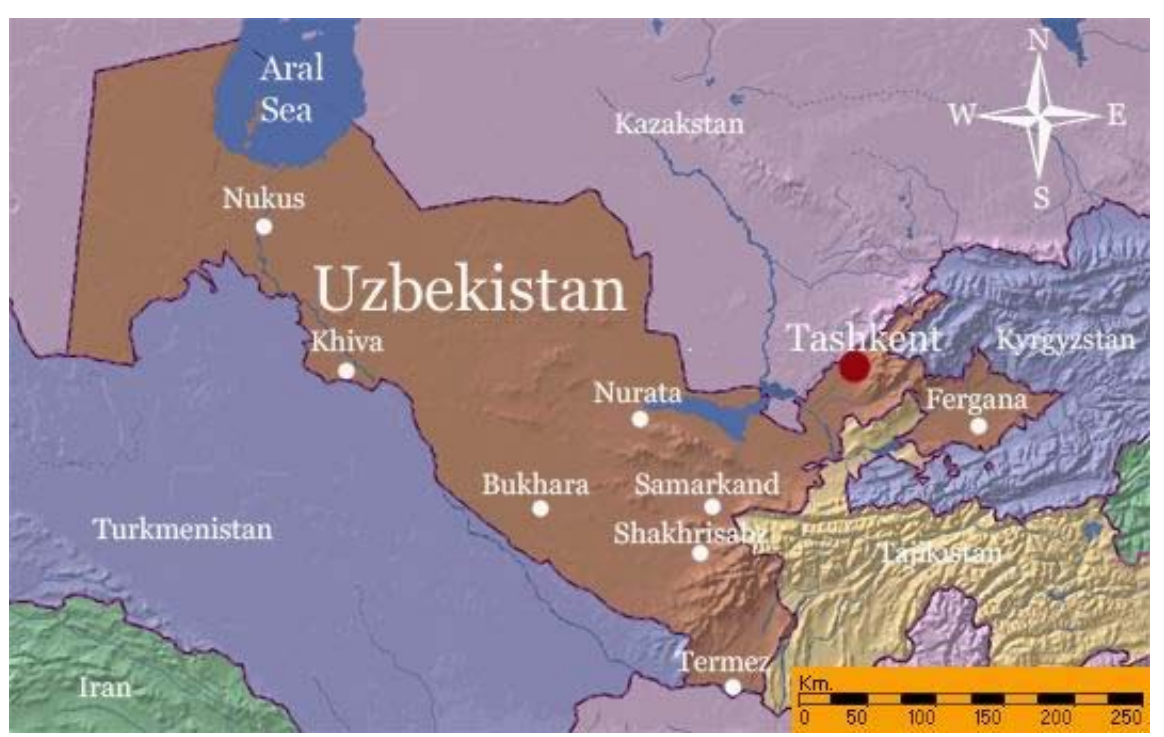

INFORMATIONS MAPS Land Boudaries Total : 6,221 km .

Geographic Coordinates : mostly midlatitude desert, long, hot summers, mild winters; semiarid grassland in east.

Area Total : 447,400 sq km .

Area Land : 425,400 sq km .

Area Water : 22,000 sq km .

Area Comparative : slightly larger than California .

Coast Line : $0 \mathrm{~km}$ (doubly landlocked); note - Uzbekistan includes the southern portion of the Aral Sea with a $420 \mathrm{~km}$ shoreline.

Railways Total : $3,950 \mathrm{~km}$.

Highways Total : $81,600 \mathrm{~km}$.

Waterways : $1,100 \mathrm{~km}(2004)$.

Ports and Harbors : Termiz (Amu Darya).

\section{Annex 2. GPS/ Location of Uzbekistan}

GPS- Area Type: Populated place. Location Type: Captial Of A Country (pcld, Pclf, Pcli, Pcls). Latitude: 41.31667; Longitude:69.25; Latitude (DMS): 41 ${ }^{\circ} 19^{\prime} 0$ N; Longitude (DMS): 69 $15^{\prime} 0$ E; 